\title{
СТАН ЗДОРОВ’Я СТУДЕНТІВ, ПРОБЛЕМИ ТА ШЛЯХИ ЇХ ВИРІШЕННЯ
}

\author{
Л. І. Чернявська, І. Я. Криницька, О. П. Мялюк \\ Комунальний заклад «Бердянський медичний коледж» \\ Запорізької обласної ради \\ ДВНЗ «Тернопільський державний медичний університет \\ імені І. Я. Горбачевського МОЗ Украӥни" \\ Рівненський державний базовий медичний коледж
}

У статті наведено статистичні дані про стан здоров’я студентської молоді, висвітлено проблему шкідливих звичок та здорового способу життя. Звернено увагу на шляхи вирішення даних проблем.

\section{STUDENTS' HEALTH, PROBLEMS AND SOLUTIONS}

\author{
L. I. Chernyavska, I. Ya. Krynytska, O. P. Myaluk \\ Municipal institution «Berdiansk Medical College» of Zaporizhzhia Regional Council \\ I. Horbachevsky Ternopil State Madical University \\ Rivne State Basic Medical College
}

The article presents current statistics data about the health of students, especially the problem of bad habits and a healthy lifestyle. Attention is drawn to the ways of these problems' solutions.

Вступ. Стан здоров'я молоді продовжує залишатися однією з найбільш гострих медико-соціальних проблем у нашій країні. В результаті складного, нестабільного соціально-економічного стану, загострення конфлікту на Донбасі, зростання кількості родин, які вимушені змінювати свій звичний спосіб життя, та, до того $ж$, недостатнього фінансування системи охорони здоров'я, погіршився стан здоров'я як дорослого населення, так і підлітків України. Вікові особливості пубертатного періоду визначають їх підвищену чутливість і здатність найбільш гостро реагувати на зміни умов життя погіршенням стану свого здоров'я [1].

Основна частина. Підлітковий вік, на думку експертів ВОО3, охоплює період життя від 10 до 18 років [8]. Разом з тим, питання вікової періодизації остаточно не розв'язано, оскільки всі існуючі періодизації недостатньо фізіологічно обґрунтовані. Вони не враховують адаптаційно-пристосувальний характер розвитку організму в цілому на кожному етапі онтогенезу. На цьому етапі завершується становлення ряду морфологічних, фізіологічних і психологічних функцій, що істотно відрізняють підлітків від дітей і дорослих. Знання цих особливостей необхідно як для адекватної оцінки стану здоров'я і його динаміки, так і для вибору раціональних заходів із надання медичної допомоги даній віковій групі. Тим часом, не можна применшувати роль педагогічних працівників у формуванні готовності молодої людини до здорового способу життя, виховання культури здоров'я, його збереження та зміцнення. Теоретично вся молодь обізнана про здоровий спосіб життя, але практично дотримуються його лише незначна частина. Відповідальність за організацію і здійснення гігієнічного навчання і виховання підлітків несуть керівники освітніх установ та медичні працівники, непряме формування здорового способу життя підлітків ведеться через вплив їх батьків.

Основною тенденцією зростання і розвитку підростаючого покоління в XX столітті було прискорення цих процесів - акселерація. Акселерація торкнулася всього періоду росту і розвитку людини, починаючи з її народження, але саме підлітки-тінейджери привернули до себе особливо пильну увагу. У цей період життя найбільш яскраво виявлялися основні риси акселерації: прискорення росту, збільшення розмірів тіла і більш ранній початок статевого дозрівання.

(с) Л. І. Чернявська, І. Я. Криницька, О. П. Мялюк, 2017 
До кінця XX століття закінчується акселерація в нашій країні, як і в ряді інших країн світу, що особливо помітно у великих містах. Поступово набирає чинності протилежний процес, який німецький дослідник І. Ріхтер назвав деселерацією [9]. Цей процес у підлітків обох статей триває і в самі останні роки. Привертає на себе увагу те, що зміни зачіпають не зміни росту, а масу тіла і обхоплювальні параметри, що зумовлює явну астенізацію статури і відповідні патології. Від цього залежить вікова готовність учня до навчання, створення навчальних програм, що відповідають віковим можливостям дітей, межам підліткового віку, що вимагає модернізації, розширення та поглиблення навчання підростаючого покоління.

За даними Державної служби статистики України, найпоширенішими хворобами серед молоді є: захворювання органів дихання (984,71 \%о); захворювання органів травлення (133,63 \%о); захворювання ока та придаткового апарату (104,35 \%о); захворювання шкіри та підшкірної клітковини (86,22 \%о); захворювання кістково-м'язової системи (84,57 \%); захворювання ендокринної системи $(83,42 \%$ \%); захворювання інфекційні та паразитарні $(65,48$ \%о); захворювання нервової системи (59,94 \%о); травми та отруєння $(57,05 \%$ \%); захворювання сечостатевої системи (53,18 \%).

На тлі подій, які відбуваються в Україні з кінця 2013 - початку 2014 р. гостро постало питання створення боєздатної армії. Саме через це проблеми, які пов'язані зі станом здоров'я допризовної молоді актуальні як ніколи, адже від цього залежить залучення молодих людей до військової служби. Але протягом останніх років спостерігається стійка тенденція до погіршення стану здоров'я допризовної молоді. За даними Міністерства охорони здоров'я України, поширеність захворювань (усі зареєстровані хвороби (гострі та хронічні), якими хворіла особа протягом року) серед юнаків 15-17 років впродовж останніх 5 років збільшилась майже на $10 \%$. Особливо різке погіршення стану здоров'я 15-17-річних хлопців відбулося у 2013 р. - 20 391,8 осіб відповідного віку на 10 тис. населення порівняно з 20 015,7 на 10 тис. населення у 2012 р., тобто протягом 2013 р. кожна молода людина віком 15-17 років хворіла більше двох разів [6].

Питанню збереження і зміцнення здоров'я учнівської молоді присвячені численні дослідження, але в основному характеризують стан здоров'я дітей і підлітків, які навчаються в школі та вищих освітніх установах, а особливостям стану здоров'я студентів, які навчаються в середньоспеціальних професійних освітніх установах медичного профілю, відображені недостатньо. Підвищеної уваги вимагають до себе студенти, які вступають у навчальні заклади з невеликих міст та сіл, оскільки в процесі соціалізації особистості, зміни способу життя і місця проживання, у молодих людей виникає необхідність вивільнення додаткового потенціалу сил організму в результаті складного адаптаційного процесу [3, 5, 7].

Студенти, як представники підростаючого покоління, складають особливий контингент населення, стан здоров'я якого $є$ барометром соціального благополуччя суспільства. Можна не сумніватися, що на їх стан здоров'я впливають численні несприятливі чинники ризику: збільшення кількості стресових ситуацій в повсякденному житті, в тому числі для студентів із тимчасово окупованих територій, посилення несприятливих екологічних впливів, ускладнення освітніх програм, а також гіподинамія, порушення режиму дня, харчування і т. д. [2].

Проведені дослідження відображають різні аспекти стану здоров'я студентів. Однією з причин погіршення стану здоров'я учнівської молоді $\epsilon$ те, що більшість молодих людей вступає до вищих і середньоспеціальних навчальних закладів вже з проблемами в галузі здоров'я.

За даними Інституту гігієни та медичної екології ім. О. М. Марзєєва НАМН України, частка шкільної молоді, яка у 2013 р. визнавалася лікарями здоровою (тобто такою, у якої відсутні хронічні захворювання і вади розвитку), коливається у межах від 9 до 45 \%. Тобто здоровими можна визнати менше половини загальної кількості школярів. У свою чергу, серед цих школярів високий та середній рівень здоров'я мають приблизно 30 \% осіб. Саме вони визнаються медиками здатними до виконання встановлених нормативів на уроках фізичної культури. Ще дві третини практично здорових школярів мають недостатній резерв здоров'я (іншими словами - низький рівень адаптаційних можливостей за станом здоров'я) і потребують негайного втручання лікарів профілактичного напрямку з метою розробки індивідуальних програм збереження здоров'я [6].

Одним із соціальних факторів, що впливають на стан здоров'я підлітка, є навчання - це складний і тривалий процес, що впливає на психіку і фізіологію молодих людей, що вимагає величезних енерговитрат. Різноманіття зовнішніх і внутрішніх факторів, що негативно впливають на здоров'я студентів, визначає необхідність системного вивчення їхнього способу життя, умов навчання і виховання. 
У процесі навчання відбувається зміна фізіологічного стану організму, що називається втомою. В учнів стомлення розвивається при інтенсивній або тривалій розумовій роботі. Втома, з одного боку, захищає від надмірного виснаження, а, з іншого боку, стимулює відновлювальні процеси і підвищення функціональних можливостей.

Якщо розглядати спосіб життя студентів із гігієнічної точки зору, то можна виявити ряд дефектів, що призводять до погіршення стану здоров'я. Передусім це шкідливі звички, гіподинамія, порушення режиму харчування, недотримання режиму дня і відпочинку, несприятливі умови проживання в гуртожитку, орендованих квартирах, підвищене навчальне навантаження, психоемоційне напруження [4].

Викликає побоювання те, що студенти не надають значення впливу харчування на стан їхнього здоров'я. Проте, доведений той факт, що споживання гарячої їжі тільки один раз на день негативно впливає на здоров'я підлітків, а також низька якість харчування, економія на продуктах, неминуча при невисоких доходах. Тому відсутність сніданку і нерегулярність обідів, обмеження в харчуванні через відсутність бажання, нестачу часу і відсутність грошей - можна віднести до причин розвитку захворювань органів травлення.

Стан здоров'я сучасних підлітків багато в чому залежить від поведінкових факторів ризику. Найбільш небезпечними чинниками для здоров'я європейських підлітків віком 12-15 років вважають куріння, вживання алкогольних напоїв, стрес, зловживання лікарськими засобами.

За результатами досліджень ЮНІСЕФ, третина українських учнів віком 11-17 років мають досвід куріння цигарок, кожен другий учень професійнотехнічного навчального закладу курить щодня, кожен дев'ятий підліток хоча 6 раз у житті вживав марихуану. За останні 4 роки чисельність учнів, котрі вживають алкоголь, залишається незмінною: кожен сьомий серед 11-річних і 76 \% серед 17-річних мають досвід вживання будь-якого спиртного напою. При цьому, кожен четвертий підліток віком від 13 до 17 років раз на місяць вживає міцні алкогольні напої, 20 \% підлітків принаймні раз у житті напивалися (6 \% серед 10-річних і $61 \%$ - 17-річних) [10].

Сучасні умови життя висувають нові вимоги до здоров'я та інтелектуальних можливостей молоді. Майбутні фахівці повинні володіти високою професійною кваліфікацією, бути здоровими, фізично витривалими, мати високу працездатність. Студенти особлива виробничо-професійна група певного віку зі специфічними умовами праці та життя. В студентів у 18 років ще повністю не завершився фізичний розвиток, збільшення маси тіла і м'язової сили у більшості студентів завершується до 19-20 років. Багато студентів живуть у гуртожитку окремо від сім'ї, що повністю змінює їх стереотип життя.

Згідно з дослідженнями фахівців ВООЗ, здоров'я населення зумовлено в 18-22 \% станом навколишнього середовища, в $20 \%$ генетичними факторами, більше ніж у 50 \% умовами і способом життя і лише в 8-10\% зі станом служби охорони здоров'я [1]. Отже, можна з упевненістю стверджувати, що здоровий спосіб життя - це надійніший засіб збереження і зміцнення здоров'я. Будучи зумовленим соціально-економічними умовами, спосіб життя залежить від мотивів діяльності конкретної людини, особливостей її психіки, стану здоров'я і функціональних можливостей організму. Цим і пояснюється реальне різноманіття варіантів способу життя різних людей.

Висновки. Оскільки формування особистості майбутнього фахівця включає турботу про власне здоров'я, а найбільш гострою проблемою є серйозне його погіршення у студентської молоді, доцільна розробка і реалізація студентами особистісноорієнтованої, індивідуальної, перспективної за часом програми оздоровлення, враховуючи значний відсоток числа студентів, віднесених за станом здоров'я до спеціальної медичної групи. Цільовою установкою освіти в галузі валеології $\epsilon$ створення стійкої мотивації до здорового і продуктивного стилю життя, формування потреби у фізичному самовдосконаленні.

\section{СПИСОК ЛІТЕРАТУРИ}

1. Баранов А. А. Медицинские и социальные аспекты адаптации современных подростков к условиям воспитания, обучения и трудовой деятельности : руководство для врачей / А. А. Баранов, В. Р. Кучма, Л. М. Сухарева. М. : ГЭОТАР-Медиа, 2007. - 352 с.

2. Васильев В. Н. Здоровье и стресс / В. Н. Васильев. М. : Знание, 1991. - С. 69-82.

3. Гигиена : учебник / Г. И. Румянцев [и др.]. - М. : гЭОТАР-Медиа, 2002. - 608 с. 
4. Даценко І. І. Гігієна дітей і підлітків : підручник. Допущено МОз / І. І. Даценко, М. Б. Шегедин, Ю. І. Шашков. К., 2006. - С. 163-165.

5. Гигиеническое поведение студентов и среднего медицинского персонала / А. В. Шабров [и др.] // Проблемы социальной гигиены здравоохранения и истории медицины. - 2002. - № 6. - С. 11-14.

6. Стратегічні пріоритети молодіжної політики: освіта, зайнятість, житло : доповідь Президентові України, Верховній Раді України, Кабінету Міністрів України про становище молоді в Україні. - К., 2014. - С. 31-34.

7. Состояние здоровья и некоторые социологогигиенические характеристики учащихся медучилищ и молодых медицинских сестер / А. Я. Дударев [и др.] // Проблемы охраны труда и здоровья женщин на современном этапе и пути их решения : сб. науч. тр. - М., 1988. - 4. 2. - С. 257-259.

8. Физиология роста и развития детей и подростков (теоретические и практические вопросы): практическое руководство / под ред. А. А. Баранова, Л. А. Щеплягиной. М. : ГЭОТАР-Медиа, 2006. - 432 с.

9. Richter I. Kontinuierlichemenardier- Beobachtungen einergeschlossr enen Population / I. Richter // Arztl. Jugendkde. - 1990. - Bd-81.

10. Korrespondent.net/ukraine/3520769-v-ukraini-koz... av-narkotyky-yunisef

Отримано 12.01.17 